\title{
Cities and states in geohistory
}

\author{
Edward W. Soja
}

Published online: 5 March 2010

(C) The Author(s) 2010. This article is published with open access at Springerlink.com

\begin{abstract}
In his last major work, Charles Tilly presents a schematic history of the development of cities, states, and trust networks over the past five millennia. I reconfigure his "look across history" from a more assertively spatial perspective, pushing back the starting point of the geohistory of cities another 5,000 years to what is presented as the first of three "urban revolutions." From this geohistorical viewpoint, cities and states do not emerge together de novo in Sumeria but the state is seen as being generated from earlier urbanization processes or what can be described as the stimulus of urban agglomeration. The generative power of cities or urban spatial causality, rarely addressed in the social science literature, is being re-discovered today as a primary source of societal development, technological innovation, and cultural creativity. In my schematic geohistory, the stimulus of urban agglomeration is traced over 10,000 years from its early role in the development of full-scale agriculture and the remarkable artistic creativity emanating from Çatalhöyük, the largest of the earliest urban settlements; through the formation of politically charged city-states and city-based empires; to the city-generated Industrial Revolution and the origins of urban industrial capitalism; ending in a look at the contemporary reconfiguration of cities and states and the shift from metropolitan to regional urbanization.
\end{abstract}

To begin his last major work, Cities and States in World History, Charles Tilly takes the reader back nearly 5,000 years to the thriving city-state of Uruk, near the confluence of the Tigris and Euphrates rivers. At that time, Uruk was already well established as one of the first fully formed city-states and probably the world's largest urban agglomeration as well, with 50,000 people living within its walls. Uruk's ruler during part of this era was the great king Gilgamesh and Tilly uses the clay tablet inscribed Gilgamesh epic to open up his own "look across history." Sketching and schematizing furiously, as he described it, Tilly presents a highly

E. W. Soja $(\bowtie)$

Department of Urban Planning, School of Public Affairs, University of California-Los Angeles,

Los Angeles, CA, USA

e-mail: esoja@ucla.edu 
personalized overview of the development of cities, states, and trust networks over the past five millennia, since what he and most experts consider to have been the original moment of city and state formation.

\section{Spatializing Tilly}

What I propose to do here, also sketching and schematizing energetically, is add a more assertive and explanatory spatial perspective to the story Tilly tells, to look at the intertwined development of cities and states across geohistory. This infrequently used term, geohistory, represents much more than adding an extra dose of geography to the writing of history or simply recognizing that "space matters." As I see it, geohistory is indicative of a radically different way of looking at history and geography together, treating them as mutually formative and co-equal in their interpretive power. (Soja 1989) Such a balanced view runs against the prevailing grain of a powerful social historicism that, since at least the mid-nineteenth century, has intellectually prioritized time over space and interpretively privileged the historical and sociological imagination over geographical or spatial perspectives. My aim in spatializing Tilly's look across history is to build on a critique of this social historicism to enrich his fundamental arguments and, more ambitiously, to open up potentially new and innovative avenues for investigating cities, states, and their coordinative networks of trust.

The need for such spatialization of even the best historical writings arises from what can be described as the Great Ontological Distortion that took place in Western scholarship in the last half of the nineteenth century. Almost entirely unnoticed in the mainstream literature was an intellectual fixation on temporal and historical perspectives that would inject a socio-historical bias into the then emerging social sciences as well as into Marx's historical materialism. Foregrounding historical interpretations of social relations, social will, and societal development, while decidedly insightful, essentially subordinated space to time, geography to history, creating an ontological predisposition that would carry over to affect epistemological debate, theory formation, and empirical analysis in all the human sciences. Cities and states, for example, came to be studied literally and figuratively "through history" while their geography or spatiality was reduced to a neutral background environment, a container of social life and history, a stage for a social drama unfolding primarily across time and only incidentally across place and space. ${ }^{1}$

One of the few to recognize this ontological distortion was Michel Foucault (1986), who quizzically asked why is it that we have come to think of time as dynamic, process, movement, development, dialectic while space tends to be seen as fixed, dead, extra-social background, or environment. Did it start with Bergson, he ponders, curious as to how such a peculiar imbalance could have developed between time and space, seemingly co-equal dimensions of both the physical and social worlds. Expecting this social historicism to be easily recognized and repaired, Foucault would move on to demonstrate in practice a more balanced and mutually causal spatio-temporal or geohistorical perspective in his major writings. Only in the past 10 years, however, has this re-balancing of historical and geographical thinking

\footnotetext{
${ }^{1}$ For more on this ontological historicism, see Edward Soja 1989, 1996, 2000.
} 
begun to occur through what some have been calling a "spatial turn" in the human sciences, as nearly every discipline and subject area has been experiencing some degree of provocative spatialization (Warf and Arias 2009).

Geohistory as it is used here carries with it an ontological re-balancing of the social, the historical, and the spatial, with no one of them given priority or privilege over the others. Given the persistence of social historicism, however, a compensatory emphasis on critical spatial thinking will need, at least temporarily, to be given primary attention no matter what the subject may be. What follows then is the product of a strategic foregrounding of a spatial perspective, exploring how it might add new insights into the study of cities and states.

At the core of this look across geohistory is an emphasis on urban spatial causality, how cities as spatially organized social formations actively shape social relations and help to stimulate societal development. Cityspace in this sense is not just a place in which social life unfolds and major events occur but is also an affective and consequential context. From what can be described as the stimulus of urban agglomeration emanates a generative force that has played a powerful but almost entirely unnoticed role in societal development as a source of accumulation, innovation, coercion, hierarchy, and cultural creativity. Jane Jacobs in The Economy of Cities (1969) was among the first scholars to recognize the generative effects of urban agglomeration and her work is used here to begin our revised look at the geohistory of cities and states. ${ }^{2}$

\section{Pushing back the origin of cities}

Tilly's look across history is rich with insights, especially with regard to the conceptualization of trust networks as integrative mechanisms holding together the intertwined evolution of cities and states. In his creative excursion, however, he is occasionally led astray by the fundamentally historicist writings of others, anddespite his unusually fertile geographical imagination-by his own intrinsic privileging of time over space, history over geography, especially in the realm of social causality. The subordination of urban spatial causality in Tilly's interpretation of the development of cities and states begins with the debate on urban origins.

Rather than beginning with the thriving city-state of Uruk and the Gilgamesh epic, the story of urban geohistory needs to be taken back another 5,000 years or more to Çatalhöyük and its even more ancient predecessors. ${ }^{3}$ Following Jane Jacobs (1969) rather than Lewis Mumford (1961), it can be argued that the world's earliest urban settlements took place in the highland belt running through southern Anatolia to present day Iran and south into the Levant rather than in the so-called Fertile

\footnotetext{
${ }^{2}$ The Economy of Cities has inspired a growing field of geographical economics dealing with "urbanization economies," the positive and negative effects that arise from urban agglomeration. Jacobs argued that without cities, we would all be poor, we would have remained hunters and gatherers as we were throughout nearly all of human existence. Some economics textbooks (see McDonald 1997) now call these effects "Jane Jacobs externalities" and argue that such urbanization economies are now the primary force behind economic development and technological innovation in the world.

${ }^{3}$ This alternative view of the origin and geohistorical evolution of cities is developed in detail in the first three chapters of Soja (2000).
} 
Crescent of alluvial Mesopotamia. Tilly refers to "Chatal Hoyuk," and also the even older Jericho, but bows to the canonical literature in dismissing these settlements as not yet "full-fledged cities," owing to a lack of central authority, signs of inequality and hierarchy, and an elaborated division of labor, not to mention an alphabet, the key to what the time-minded call "written history" and city-based "civilization."

The debate about whether Çatalhöyük and Jericho were truly cities is entangled in a kind of Catch-22 that brings into question nearly all existing histories of the origins of cities and states, including Tilly's. So fixated is the literature on the Sumerian city-states such as Uruk and Ur that the definition of a city becomes confusingly conflated with the definition of the state. That is, if a settlement does not express the key features of a centralized and hierarchical state, then it cannot be a true city. Adding to the confusion, large-scale agricultural development is thrown in as essential to the formation of both cities and states, with cities as well as states seen as evolving from expansive agricultural villages through an increasing social division of labor. That cities as permanent and generative urban agglomerations can form without states is generally ruled out, as is the even more audacious possibility that urbanization preceded - and stimulated - full scale agricultural development.

The deeply held belief that the production of a social surplus, primarily in food, was essential to the formation of cities was turned upside down by Jane Jacobs in The Economy of Cities. Building on excavations at Çatalhöyük in the late 1960s (knowledge unavailable to Mumford when writing The City in History), she claimed that cities came first, before the Agricultural Revolution, implying that cities were essential to the production of a social surplus rather than the other way around. She argued, to the ridicule and dismissal of most prehistorians and paleoanthropologists, that the first substantial human settlements were stateless cities formed by egalitarian bands of hunters and gatherers well before the development of "full-fledged" agrarian societies. They were, in essence, Neolithic cities, an impossible and contradictory phenomenon to most scholars of antiquity.

Cities almost surely did not precede the domestication of plants and animals and there were people who knew how to farm in the first cities. But what is clearly suggested from contemporary archeological evidence and the logic of distanceminimizing human spatial behavior is that urbanization and agricultural development evolved together in a mutually causal and symbiotic relationship. The creation of an agricultural surplus played a key role in stimulating the development of cities, but just as important (and often overlooked entirely), urbanization played a generative role in the Agricultural Revolution. Understanding this mutual causality, which, as we will see, can also be applied to the development of the state, builds upon the recognition that the first true cities were formed around 12,000 years ago in Southwest Asia and that this epochal commitment to living densely and permanently together in one place rather than maintaining a roving nomadic existence marked a kind of "big bang" in the development of human societies.

Once humans decide to settle in one place, as one of the excavators of Jericho put it (Kenyon 1960), all else follows: the geohistory of societal development begins. The settling down into permanent urban clusters was perhaps the most revolutionary event in the history of human society, following after at least 2,000,000 years of existence as small nomadic bands of fewer than a hundred members. Almost surely, these first cities could never grow to much more than 10,000 inhabitants, but this 
was an explosive leap in societal scale and complexity. Environmental factors played an important role in these changes, as a period of global warming melted back continental icecaps and encouraged the intensification of traditional hunting, gathering, and fishing technologies in the well watered zone from the Mediterranean to southern China. Permanent urban settlement, however, is better understood not as environmentally induced but as a rational and specifically spatial choice.

While knowledge of farming existed - there is evidence of plant domestication going back 18,000 years - the vast majority of inhabitants of the first cities were hunters and gatherers. There is no clear evidence of early agricultural villages that somehow grew into cities. Indeed, the idea that reasonable people would cluster together in permanent dwellings to farm does not make sense, especially when defense against outsiders was not a factor. If anything, the reverse was more likely, that urban agglomeration led to the spawning off of the first agricultural villages and small settlements of livestock keepers, initially to serve the needs of the urban population although later seeking greater autonomy as a rural peasantry and nomadic pastoralists.

So what led hundreds and in some cases thousands of people to create the first permanent urban settlements? Not farming or rearing livestock (which were possible to practice 12,000 years ago), nor hunting and gathering, but trade and exchange, probably through some means of reciprocity. There is evidence that long-distance trade existed in Southwest Asia and the eastern Mediterranean 15,000 years ago and may have created ancient trade routes that would later evolve into the famous Silk Road Tilly writes about, stretching across Eurasia to connect with another wellspring of urbanization in the loess plains and river valleys of northern China.

Trade then was the primary urbanizing force, especially in the Neolithic or New Stone Age, when the main commodity was workable stones such as flint and obsidian, the volcanic glass that was most closely associated with the growth of Çatalhöyük. Choosing an actual site probably was influenced by natural factors such as the availability of water supplies, including lakes and marshes with abundant wildlife, but gathering together thousands of inhabitants was mainly a logical and efficient response to the trade of heavy goods, especially in comparison to delivering them to scattered nomadic encampments. This also meant that there were probably many smaller trading centers along the main routes. From the start then, urbanization probably took the form of a network of settlements of various sizes rather than isolated and insulated cities. ${ }^{4}$

Çatalhöyük, perhaps the major metropolis of the Neolithic, lasted for nearly 2,000 years, shifting about on two mounds and probably rising and falling in size before being abandoned. Its generative power was impressive, leading to expanding agricultural development, innovative architecture and urban design, a form of highly egalitarian and family based religion, and the greatest burst of artistic creativity in human geohistory up to that time. The most brilliant of earlier cave paintings almost always represented hunting scenes or elaborate geometric patterns. A few wood or

\footnotetext{
${ }^{4}$ Whether forms of identity and trust coincided with these urban networks we may never know, although the egalitarian character of the first cities suggests a strong family focus and household autonomy rather than a large scale community identity.
} 
stone sculptures of what are thought to be fertility goddesses have been found, but what happened in Çatalhöyük was extraordinary.

Hundreds of goddess-like sculptures were produced (possibly stimulated by the gradual shift from hunting to agriculture), metal including copper was worked into elaborate designs, the first known textiles and rugs were woven, obsidian was cut and polished into the first hand-crafted mirrors, and beautiful murals were painted, including one that almost surely is the first known example of a cityscape, a depiction of dozens of houses spreading out in front of a distant twin-peaked volcano seemingly erupting with the invaluable obsidian the city depended upon. Here then was abundant evidence of the transformation of nature into socialized cityspace, representing the "cooked" rather than the "raw" in Levi-Strauss's terms. In the previous 2,000,000 years of homo sapiens existence, there was nothing to compare with the urban generated artistic and cultural revolution that took place in and from this remarkable Anatolian city.

\section{Emerging polities: the city and the state combined}

Derived from this radically revised view of societal development is the idea that cities and the urbanization process have provided perhaps the most important generative force behind every major breakthrough in human geohistory, from the agricultural to the industrial revolutions to major bursts of artistic creativity and technological innovation. From about 8,000 to 5,000 years ago, the stimulus of urban agglomeration also played a key role in the formation of the state and centralized authority, the emergence of hierarchies of differential social power, the rooting of this hierarchy of power in gender, kinship and cultural ties, and the rise of class divisions based largely on the ownership of property. So closely tied were urban development and state formation that what emerged during this period is called the city-state or, from the Greek, the polis, which some dictionaries define as meaning either city or state.

Recent excavations in Anatolia as well as northern Syria and Iraq suggest that the earliest stateless or acephalous cities evolved over thousands of years into the citybased states of Mesopotamia and probably also the Nile and Indus Valleys. Çatalhöyük had no formidable walls around it and there was no evidence of any political or religious centrality within the settlement. Households were roughly similar, with few shared walls so that one family could remain in the same home site for many generations, each one buried atop the others. (Hodder 2006) After around $8,000 \mathrm{BP}$, however, before the flowering of the Mesopotamian city-states, evidence of walled settlements has been found showing signs of increasingly centralized authority and growing hierarchy, with some buildings much larger than others and with urban spaces possibly devoted to ceremony and/or exchange. Interestingly enough, no evidence was found at these sites of written language.

What this suggests, as noted earlier, is that urbanization and state formation grew together symbiotically, very much like the mutually stimulating development of cities and agriculture that was also continuing to occur in the new environments of the great river valleys of Eurasia and northern Africa. That state formation and large scale irrigated agriculture influenced urban development is not a new idea, but there 
is very little written that emphasizes on at least an equal basis that cities generated states and all their appurtenances, from centralized royal and religious authority (with the skyscraping ziggurat its synecdoche), class stratification, expanding patriarchal power, military force, and empire-building impulses. The state was not only reflected in the built environment and social geography of the city, it emerged from the urban context or habitat. It truly was a city-generated-state or, just as descriptive, a state-generated-city. To make one generative process more important than the other, or to see either as developing separately, is to distort what happened.

To be clear, I am not claiming that urbanization explains all aspects of societal development or state formation, although I am purposefully emphasizing the importance of urban spatial causality largely because it has been virtually invisible in the existing literature and, in particular, in the writings of historians and social scientists on states and cities. I hope that at least a glimmer of these ideas was behind Tilly's frequent challenges to urban historians to find more exciting and interesting things to say about cities than simply chronicling events, but I cannot be sure. Just as it is widely assumed that the agricultural revolution preceded and led to the rise of the first cities, so too do the majority of scholars see state formation (and written language) as pre-requisites for the growth of true cities. As I have been arguing, the reverse is much more likely, with urbanization preceding and leading to (or coevolving with) the transformative processes associated with the rise of agrarian societies and the formation of the centralized state.

The stimulus of urban agglomeration began to have an effect 12,000 years ago, reached an early peak in Çatalhöyük, and would explode again in Sumeria with the formation of city-states, which would subsequently spread or be independently invented in many different regions around the world. Tilly picks up the story in Uruk and the Gilgamesh epic. While he is almost surely correct in stating that "no states existed anywhere in the world before 4,000 BCE" or 6,000-plus years ago, he is almost surely wrong in accepting the argument that cities first appeared in the same periods and places as states, as depicted in a canonical and historicist literature that muddles together the definitions of city, state, and even more Eurocentrically biased, civilization.

For the most part, Tilly avoids this definitional confounding in his commentary on the "ambiguous" and variable relations between cities and states as distinctive entities, but he develops a typology and a "main historical trend" (see Figure 1 in Tilly's article in this issue) that confuses more than clarifies these relations. The trend line expresses the familiar idea that the world has moved from a time when cities dominated to a time closer to today when centralized states became more powerful than cities. There may indeed be a trend toward increasing state versus urban power, but the coordinates of Tilly's diagram confound how this trend is framed and interpreted.

In the upper left corner of the diagram is the "autonomous city," a remarkably empty but seemingly originating category that Tilly awkwardly exemplifies in contemporary Hong Kong and the Vatican, but not Singapore, which is more like the (non-autonomous?) "city-state" appearing at the more "integrated" upper right hand corner. The city-state represents an extreme of urban dominance, while the centralized state (China is described as a formidable example) is planted at the other lower right and culminating extreme, when states were dominant. Left over in 
the lower left corner (states dominant but "segregated" rather than integrated) are nomadic empires.

What is buried under this Autonomous Cities, City-States, Centralized States, Nomadic Empires classification is the constant generative force of cities, the possibility that all human societies have been urbanized societies for the past 12,000 years. First of all, no cities are ever autonomous, from nature, from state power when it exists, or from networks of trust. Furthermore, city-states are also centralized states. They may not be nation-states, but this is another story. And while nomadic empires may be less urbanized and centralized than other empires, few if any are entirely disconnected from important cities and their generative effects. Yes, nation-states have become more powerful bastions of coercion and social control than city-states, but they have always ruled through cities and the accumulation of national wealth has always hinged primarily-but never exclusively-on the stimulus of urban agglomeration.

Tilly's diagram and discussion of the rise of national state power, earlier in Europe than elsewhere, reflects and reinforces the conventional social historicist view that has led to the submergence of urban spatial causality and the privileging of socio-historical processes as opposed to a more balanced socio-spatial and spatiotemporal dialectic. After Westphalia, the story goes, cities become less important while the state grows in social power, leading too easily to the idea that with the formation of the nation-state scholars can henceforth forget about urban spatial causality, the generative power of cities, and urbanization as the driving force behind economic development. Cities were mummified in Western social and political theory, especially as causal factors (with a few exceptions, such as the old Chicago School). Things happen in cities but not because of cities. Even the urban in urban industrial capitalism, part of another major city-generated revolution, disappears from view and hence from systematic analysis in socialist theory. The existence of the national state as a fundamentally spatial or territorial form also tends to be forgotten as states become abstracted from cities and the urbanization process.

There is much more to be explored in the co-evolution of cities and states between 5,000 and $300 \mathrm{BP}$, the onset of the industrial revolution and the rise of new urbanization processes, but I focus briefly here just on the concept of politics. As there was no evidence of an organized polity or centralized authority, it can be said that there was no true politics in the earliest cities, although some degree of social regulation was needed and probably existed to maintain a permanent urban settlement, even if only derived from a gender or inter-household division of labor. Almost by definition, however, we can claim that politics emerges in conjunction with the formation of the city-state.

In his provocative genealogy of the concept of citizenship, Engin Isin (2002) roots his analysis of "being political" in the urbanization process, in the generative forces that arise from the socio-spatial agglomeration or clustering together of urban communities. ${ }^{5}$ Following Aristotle, Isin argues that politics are essentially urban

\footnotetext{
${ }^{5}$ I have used the term synekism to refer to the stimulus of urban agglomeration, borrowing it from the Greek synoikismos as used by Aristotle and Thucydides to describe the formation of the city-state. (Soja 2000) Synoikismos refers to social groups coming together to live interdependently in one home space, oikos meaning home, the root of economics and ecology as well as ekistics, the study of human settlements. It also means to wed, to live interdependently together.
} 
generated, intrinsic to the city-state or polis, and reflective of deepening inequality of power and wealth. Without a sense of urban spatial causality, this argument becomes incomprehensible and almost impossible to understand and accept. Yet it is a vital part of what was happening in the eastern borderlands of the Mediterranean starting 8,000 years ago, as peaceful and egalitarian stateless cities became politically charged city-states.

This mutually formative relation among cities, states, and politics is blurred and fractured in most of the literature shaped by social historicism, which tends to avoid any hint of urban spatial causality. The connections, however, are clearly expressed in language and our urban-related vocabulary. The city-state or polis gives us policy, polite, police, polity, and, of course, politics; while the Latin civitas is linked to civil, civic, citizen, civilization, and city. The Greek word to distinguish the urban dweller from the barbarian outsider or rural idiotes (hence Marx's lament about the "idiocy" of rural life) is polites, a term redolent of the link between being urban and being political.

Although it would require a great deal more research than has been done or that I can do to demonstrate conclusively, I would not be surprised if this interdependency among cities, states, and politics was fairly well understood by philosophers and historians before the mid-nineteenth century rise of social historicism. It is also likely that these interdependencies have subsequently been buried, distorted, or overlooked, indeed made to appear inconceivable to modern scholars. Explicitly recognized, however, they give new meaning to what happened in that second urban revolution. Emerging was a pronounced differentiation of social and spatial power, the creation of hierarchy based on kinship ties, gender, property ownership or class, and place of residence, not just urban vs. non-urban but also location within the more centralized and less egalitarian built environment, all sustained by new forms of coercion and social control.

New populations entered the city and the urban fabric. A religious and political elite, increasing its powers of coercion and control, settled in the most favored places; a merchant class entered the city and took control of their turf; the military were given a place to live and work, as were other groups such as city-managers or bureaucrats and slaves. Cities grew in size to more than fifty thousand and competition for resources, trade, and plunder led to empire-building, as one city-state attempted to control other city-states to receive tribute in labor and goods. Geographically uneven development and globalization began to intensify, at least in the Old World, while city-states also multiplied in New World regions. City-based states and trust networks grew together, stimulating the spatial concentration of power over the accumulation of wealth and the coordination of Tilly's three Cs: capital, coercion, and commitment. These concentrations of wealth and power were not social abstractions but were concretely expressed in spatially organized citystates/state-cities, symbolically and physically punctuated by palaces, markets, castles, and churches.

Trade continued to be a vital part of urban development, as it had been from the start, but the largest transformative factor in the expansion of the city-state was more connected to the geographical efficiency of centralized territorial administration. Coercion, coordination, and commitment do not operate only in the abstract but in organized nodal spaces taking advantage of unusually intense "urbanization 
economies" of administration and the wielding of power. Managing much larger scale urban societies increased the pressure to innovate not just in coordinating labor for expanding agricultural production but for maintaining imperial control over increasingly far-flung tributary territories. ${ }^{6}$ The growth of individual cities as well as the population size of city-based empires increasingly hinged upon administrative and managerial capacity and innovativeness.

\section{The industrial capitalist city: a third urban revolution?}

The city-state and city-state based empires evolved in many different directions from their earliest forms. For many (Western) scholars, the medieval city represented a particularly inspired version of urbanized society, while others saw new freedoms emerging in the mercantile cities of Europe, signified in the Hanseatic League motto stadt luft macht frei. With the possible exception of the Greek philosophical discourse on democracy, this association of freedom with the city was a relatively new idea, reflecting the emergence of merchant based rather than state based cities. The rise and globalization of mercantile cities, many without significant state functions, had another geographical effect, leading to a rapidly growing coastal urbanization process, as port cities and long distance trade routes connected the littoral of all the worlds inhabited continents and contributed to the relative decline of some city-states located deeper inland.

The urbanization process and the stimulus of urban agglomeration changed dramatically with the Industrial Revolution. As recent research in geographical economics has been telling us, the human activity that benefits most from urban agglomeration and urbanization economies is factory-based manufacturing or large scale industrialization. The Industrial Revolution accordingly triggered an exponential surge in urbanization unlike any that preceded it. The proportion of the world's population that lives in cities remained very low, probably well under $1 \%$, for the first 6,000 years of societal development. It rises only slightly over the next 5,000 years through the age of the city-state, but explodes in the late eighteenth century, when some states such as Great Britain and the Netherlands became predominantly urban for the first time as a third mode of urbanization emerged in association with the growth of the industrial capitalist city.

By 1800 , something remarkable had happened to the urbanization process. In the new kind of city, industrialization, capitalist economic development, the expanding power of the centralized nation-state, and what scholars began to call "modernization" became inextricably linked to urbanization. The macro-geography of this third urban revolution was quite different from the first two, with their origins primarily in Southwest Asia. Although there was a tendency to Europeanize the global development of the city-state, favoring Greek and Roman experiences (something Tilly assiduously avoids), industrial capitalist urbanization in its initial stages was

\footnotetext{
${ }^{6}$ Among the largest urban agglomerations before the rise of the nation-state were Teotihuacan in present day Mexico, Xi'an (Sian) in China, Angkor in Cambodia, and, with perhaps as many as a million inhabitants, dynastic Alexandria and imperial Rome. There is still very little known about why some cities grew faster and were more generative than others. The literature addressing this question is sparse.
} 
decidedly focused on northwest Europe, at the outer edges of the old Roman empire in the British Isles and Euro-lowlands.

The great imperial and commercial centers of London and Amsterdam would feel the effects of industrialization on a grander scale than most other cities, but perhaps the "purest" expression of the radically new urbanization processes took place in Manchester, which, from a small market town, grew by 1850 to over a million inhabitants as the second largest English city, after London. Manchester's (like London's and Amsterdam's) industrialization was in large part a product of the globalization of mercantile capitalism and the formation of trading networks along the inhabited coasts of all the world's continents.

Manchester illustrates paradigmatically the intertwined co-evolution of urbanization and industrialization in a chicken and egg dynamic resembling what happened earlier with regard to agricultural development and state formation. Stated differently, the industrial revolution and the expansion of urban industrial capitalism were generated and carried forward in and from cities. The conventional wisdom barely recognizes or totally rejects this possibility. After all, the historians say, weren't the first factories built along rural streams where rapids helped to generate needed power? But just as it can be said that, while some settlers in the first cities knew how to farm, the full-fledged Agricultural Revolution grew out of the urbanization process and the stimulus of urban agglomeration, so too can it be argued that the expansive Industrial Revolution could not have developed as it did without the generative force of urban spatial causality.

A brief look at the internal geography reinforces this view. Urban growth was fueled primarily by the entry of three sizeable populations that were not present in preindustrial cities to any significant degree. First was the industrial bourgeoisie, the factory owners, who with their growing economic power could take up the most favored locations both in the center (often displacing the mercantile petit bourgeois residents) and outside the core city, in rural manors and villas once the exclusive preserve of the aristocracy. Much larger in numbers was the urban proletariat, torn away from the possibility of making a living other than by selling their labor in the city. Adding to this highly centralized urbanization process was a free-floating population (Marx's lumpenproletariat) that provided both a labor reservoir and, in their miserable conditions, an effective tool to keep the working class from challenging the new economic system too vigorously. For the first time in geohistory, urban slums, poverty, and inequality served positive accumulation and integration functions.

In the first phase in the development of the industrial capitalist city, the workers, the jobless, and the majority of machine-driven factories were overwhelmingly concentrated around the city center, where the stimulus of urban agglomeration was at its peak. Centripetal forces were enormous, as industrial producers gorged on the urbanization economies welling up in the city centers. Strong tendencies toward concentricity helped to shape the sociospatial order of the city, creating the geographical regularities noticed first by Engels in Manchester and later conceptualized by the spatially oriented Chicago School of Urban Ecology. (Soja 2000) By the end of the nineteenth century, such dense centrality spawned political unrest and sparked a selective and centrifugal decentralization that would continue to the present in the form of metropolitan urbanization and suburbanization. 
The evolution of the state and state theory over the past two centuries is usually treated separately from the geohistory of urban industrialization, or marked with a triumphal note proclaiming the decline of urban social and spatial power. From a contemporary spatial perspective, however, it may be more accurate to say that the state consolidated around a multi-scalar and hierarchical national urban system that wove together administrative functions, the provisioning of services, commercial interaction and trade, and the surging growth of urban industrial production. In some states, all these hierarchies converged at the top in such dominant cities as London and Paris. In many others, the major political and economic cities differed. In all cases, however, it would be misleading to say that cities and urban power were simply subordinated and subsumed by the state. Citizenship was no longer defined by the city region of residence but it functioned and was sustained by an urban focused legal system and the overarching power of the iconic "capital" city.

Continuing to sketch and schematize furiously, the industrial capitalist city and state can be seen as developing together through a remarkably regular series of lengthy boom periods, such as that which followed after 1848 and the Second World War, and equally long periods of what can be called crisis-generated restructuring, when new forms of capitalist development and urbanization took shape. Until roughly around 1970, national states consolidated their political and economic power and sovereignty so powerfully that the world seemed to consist only of state actors, now expanded in number through de-colonization. The flat map of the international state system took hold of the academic and popular imaginations to such a degree that nearly all other sources of political power and authority seemed to disappear and alternatives were almost inconceivable.

\section{The contemporary reconfiguration of cities and states ${ }^{7}$}

Over the past 30 years, as almost everyone agrees, the sovereignty and power of the nation-state has come under greater challenge than at any other time since the establishment of the nation-state system. This has certainly not led to the end of the nation-state, as some writers prematurely presumed, but it has involved a profound restructuring or reconfiguration that has become the subject of a growing new literature. As these past 30 years have also seen a marked spatial turn in the social sciences and humanities, it is not surprising to find that an important segment of this new literature on state restructuring has emphasized a highly salient critical spatial perspective (Brenner 2004; Fraser 2008).

During the same period, the urbanization process and urban theory have been experiencing an equally profound restructuring. Many are proclaiming an emergent new urban age, drawing encouragement from the UN announcement that the majority of the world's population, more than 3.3 billion people, now live in cities. Others, with the same "end of" exaggeration applied to the nation-state, argue that cities are becoming obsolete

\footnotetext{
${ }_{7}^{7}$ I have only read the first chapter of Tilly's Cities and States in World History, so do not know how he would deal with the past two centuries. In his continuing connection of accumulation, coercion, coordination, commitment, and trust, there is at least the suggestion that our views of capitalist urbanization and state formation are not entirely incompatible. In this concluding section, however, I try to clarify the main source of our differences and to illustrate further the new ideas that are generated by emphatically spatializing Tilly's look through history.
} 
with the distance-compressing new information and communications technologies. So what can we say about this profound reconfiguration of cities and states? How different from their predecessors have cities and states become?

There has been broad agreement that three interactive forces have been primarily responsible for the restructuring of cities and states in the contemporary era. The new technologies have played a facilitative role in fostering an accelerated globalization of capital, labor, and culture and the formation of what is summarily called a "New Economy," variably described as postfordist, information intensive, flexible, and global. While evidence of the effects of these three forces can be found nearly everywhere to some degree, they combine in unique ways in every city and state to pose new challenges to interpretation, comparative analysis, and theory-building.

Faced with this complexity of outcomes and in keeping with my assertively spatial emphasis, I focus here on two closely related aspects of the contemporary restructuring of cities and states: rescaling and regionalization. Rescaling refers to the re-organization of the spatial scales and hierarchical structures through which cities and states operate. Scale has conventionally been seen as rigidly defined and almost naturally given. Influenced by the spatial theories of Henri Lefebvre, many geographers conceptualize scale as socially produced and capable of being reorganized in many different hierarchical arrangements. Particularly important are the relations between the national and supranational scales on the one hand and urban, metropolitan, and regional scales on the other. The notions of rescaling and regionalization in this sense provide a specifically spatial framework for understanding the co-evolution of cities and states.

Three distinct scales of government are usually associated with the nation-state. At the top is the national government, with clearly defined and almost always superior powers of coercion, accumulation, coordination, and the maintenance of national trust, using Tilly's terms. Local government (or the local state) has its own distinct responsibilities, with cities and municipalities often given additional functions and autonomy. In between, depending on many geohistorical variables, are regions, provinces, states, and other "mesogeographical" authorities. At each of these levels, there are designated capital cities and administrative headquarters where power is geographically concentrated to varying degrees.

For more than a century, these territorial hierarchies remained relatively stable in most states, adjusting only slightly if at all to changing political, economic, and cultural conditions. Over the past 30 years, however, these governmental structures have become more fluid, leading some to speak of simultaneous processes of deterritorialization and reterritorialization, whereby some longstanding territorial authorities experience significant changes while at the same time new and different territorial forms begin to emerge (Brenner 2004). While economic restructuring at the global scale has been extensive, however, the governmental structures of the territorial state have tended to change much more slowly, giving rise to a multi-scalar series of what many perceive to be crises of governance. ${ }^{8}$

\footnotetext{
${ }^{8}$ The growing use of the term "governance" rather than government is itself a reflection of state restructuring and rescaling. To the degree that rigid governmental structures continue to resist significant changes, the relations between the political and economic organization of the state tend to become increasingly dysfunctional. Rather than trying to change existing governmental systems, attention often shifts to creating alternative forms of regulatory governance that are more flexible and adaptive.
} 
While manifested most clearly in the hierarchal structures of the nation-state, crises of governance can be identified at many different geographical scales, from the global to the local. Intensifying environmental challenges arising from climate change and global warming as well as worsening political problems linked to global geopolitics and economic crises have focused attention on the weaknesses of existing international authorities such as the United Nations and the World Bank. Similar but much smaller scale problems have been on the rise with local government, as existing structures seem no longer to be able to handle increasing problems of poverty, infrastructure repair, and public health and safety.

The rescaling and regionalization of state power is a response to these global and local tensions. As the global economy becomes more integrated and reconstituted around a new hierarchy of global or world cities and city regions, national boundaries become more porous and the territorial exclusivity of the nation-state, its ability to act without challenge on what happens within its boundaries, is diluted. We have not yet reached a "borderless world" or the "end of the nation-state," but profound changes have been taking place globally, nationally, regionally, and locally.

Among the most important effects of globalization and economic restructuring has been a resurgence of regionalism above and below the normal scale of operations of the nation-state. Building on the model of the European Union, the first confederation of industrialized states in geohistory, has been a proliferation of multistate trading blocs such as NAFTA, MERCOSUR, ASEAN, and many others, filling in what 50 years ago was a virtually empty supranational scale, between the national and the global. Similarly, there has been a worldwide resurgence of subnational regionalisms, from Quebec and Catalonia to Eritrea and Aceh. The metropolitan regional scale also seem to be changing rapidly with the growth of expansive, polynucleated city regions increasingly asserting themselves as driving forces in the global geopolitical economy (Scott 1998, 2001). This has given new meaning to such terms as the city-state or, in a more recent invention, the "region-state" to describe such quasi-autonomous entities as Quebec or Catalonia.

It is important to note, however, that supranational and subnational regionalization have not necessarily weakened the power of nation-states. As notably exemplified in the resuscitated nationalisms (or perhaps statisms is a better word) of some members of the European Union, the state may not be losing power but enhancing it through rescaling its activities, that is, continuing to be in control of supranational developments while also using decentralization and devolution policies to maintain rather than transfer authority over its internal urban and regional governments. What is clear is that we cannot generalize about whether the state is gaining or losing power and sovereignty in the current era, but we must realize that the nation-state system is no longer what it used to be and requires new modes of understanding and analysis.

Similar processes of rescaling and regionalization have been affecting the modern metropolis. In Postmetropolis (2000), I described this crisis-generated urban restructuring as a product of globalization, the new economy of flexible capitalism, and the revolution in information and communications technology. Hedging somewhat, I described what was happening as the postmetropolitan transition. More recently, I have emphasized the emergence of a new development process I have called regional urbanization (Soja 2009, 2010). 
Regional urbanization began at least 30 years ago, layering into what has been for more than a century a process of metropolitan urbanization. Metropolitan urbanization has become so familiar and intensely studied that, like the nationstate, it is frequently considered to be the only conceivable form of urban development. The stereotypical modern metropolis tends to be monocentric, annular in the sense of having some identifiable concentricities, most notably a pronounced dualism between an urban core and various rings of suburbanization. There is almost always a steep density gradient, dropping off from a highly centripetal central business and government district, and flattening out in a much less dense suburbia, consisting of many municipalities the majority of whose working residents commute to employment centers in the urban core. Urbanism and suburbanism represent very different ways of life, the former more culturally and racially heterogeneous, and filled with galleries, museums, high crime rates, widespread drug use, and thick layers of social interaction while the suburbs are more homogeneous, monotonous, healthy-you know the rest.

All this has begun to change with regional urbanization. The metropolis has become increasingly "unbound" in an urban variation of deterritorializationreterritorialization. The once clear border between urban and suburban is blurring significantly as the density gradient begins to flatten through a paradoxical urbanization of suburbia and a selective hollowing out of the inner city, in some cases to be refilled with flows of immigrants from around the world. It seems as if the city is being turned inside-out and outside-in at the same time. As inner boundaries blur, so too does the outer boundary of the regional city become less distinct, as the urban reaches outward to a global scale. The "postmetropolis" becomes more polycentric, enmeshed in a larger network of cities, and a new urban form, the global city region, emerges in between the subnational and metropolitan scales. ${ }^{9}$

The unbounding of the modern metropolis, as in part the product of the globalization of the urban, creating the most culturally and economically heterogeneous cities the world has ever seen, has been at the same time leading to the urbanization of the entire globe. It is this extension to its limits of processes begun hundreds if not thousands of years ago that is driving the rescaling and regionalization of cities, states, and their networks of trust, coercion, regulation, and identity formation. It both concludes our look through geohistory and opens up challenging new avenues of investigation.

Open Access This article is distributed under the terms of the Creative Commons Attribution Noncommercial License which permits any noncommercial use, distribution, and reproduction in any medium, provided the original author(s) and source are credited.

\footnotetext{
${ }^{9}$ To mention just two extreme cases of these changes, the expanded city region of Shanghai, covering most of the Yangtze River delta, has recently been estimated to contain 82 million inhabitants and several other megacity regions or megalopolitan regions (both new terms) now exceed 50 million. Just as startling, the urbanized area of Los Angeles (a relatively new census category roughly coincident with what was called the built-up area) passed Greater New York as the densest in the country, as millions of immigrants concentrate in the urban core while LA's classic suburbia becomes increasingly urbanized.
} 


\section{References}

Brenner, N. (2004). New state spaces: Urban governance and the rescaling of statehood. New York: Oxford University Press.

Foucault, M. (1986). Of other spaces. Diacritics, 16, 22-27.

Fraser, N. (2008). Scales of justice: Re-imagining political space in a globalizing world. New York: Columbia University Press.

Hodder, I. (2006). The Leopard's tale: Revealing the mysteries of çatalhöyük. New York: Thames and Hudson.

Isin, E. (2002). Being political: Genealogies of citizenship. Minneapolis: University of Minnesota Press. Jacobs, J. (1969). The economy of cities. New York: Random House.

Kenyon, K. (1960). Archeology in the holy land. London: Ernest Benn.

McDonald, J. F. (1997). Fundamentals of urban economics. New York: Prentice Hall.

Mumford, L. (1961). The city in history. New York: Harcourt, Brace and World.

Scott, A. J. (1998). Regions and the world economy. New York: Oxford University Press.

Scott, A. J. (2001). Global city-regions. New York: Oxford University Press.

Soja, E. W. (1989). Postmodern geographies: The reassertion of space in critical social theory. London: Verso.

Soja, E. W. (1996). Thirdspace: Journeys to Los Angeles and other real-and-imagined places. Oxford: Blackwell.

Soja, E. W. (2000). Postmetropolis: Critical studies of cities and regions. Oxford: Blackwell.

Soja, E. W. (2009). Regional planning and development theories. In N. Thrift \& R. Kitchin (Eds.), The international encyclopedia of human geography. Amsterdam: Elsevier.

Soja, E. W. (2010). From metropolitan to regional urbanization. In A. Loukaitou-Sideris \& T. Banerjee (Eds.), Urban design: Roots, influences and trends. London: Routledge.

Warf, B., \& Arias, S. (Eds.). (2009). The spatial turn: Interdisciplinary perspective. London: Routledge.

Edward W. Soja is Distinguished Professor of Urban Planning at UCLA and occasional visiting professor in the Cities Programme at the London School of Economics. His major books include Postmodern Geographies (1989), Thirdspace (1996), and Postmetropolis (2000). His most recent book is Seeking Spatial Justice, an analysis of labor-community coalition building and struggles over the right to the city in Los Angeles, published in 2010 by University of Minnesota Press. 